\title{
PENGARUH BELANJA PEMERINTAH PUSAT TERHADAP PENERIMAAN NEGARA BUKAN PAJAK PADA KEMENTERIAN NEGARA/ LEMBAGA PERIODE 2012-2017
}

\author{
Puji Wibowo* \\ Badan Pendidikan dan Pelatihan Keuangan, \\ Kementerian Keuangan, Jakarta \\ puji.wibowo@pknstan.ac.id \\ Yoopi Abimanyu \\ Badan Kebijakan Fiskal, Jakarta \\ yoabim@gmail.com \\ Heri Syafardi \\ Direktorat Jenderal Anggaran, Jakarta \\ herisyafardi@gmail.com
}

\author{
Muhadi Prabowo \\ Badan Pendidikan dan Pelatihan Keuangan, \\ Kementerian Keuangan, Jakarta \\ muhadi.prabowo@pknstan.ac.id \\ Iin Indrawati \\ Badan Pendidikan dan Pelatihan Keuangan, \\ Kementerian Keuangan, Jakarta \\ iindrawati05@gmail.com
}

*Alamat Korespondensi: puji.wibowo@pknstan.ac.id

\begin{abstract}
Various studies evaluate the impact of budget on government revenue at sub national levels. There are few empirical findings that show how central government budget may influence federal revenue collected by ministries. This study aims to investigate the budget impact of non tax revenue across Indonesian line ministries/agencies in the 2012-2017 period prior to the implementation of Act 9 Year 2018 concerning Non Tax Revenue. By using purposive sampling method, we found there were 24 government institutions observed in this study. We conducted granger causality and panel data analysis by adopting random effect model to examine the effect of goods and services expenditure, capital expenditure, and employee expenditure on non-tax revenue. It is concluded that only government spending on goods and services significantly affects on non-tax revenue performance, while the two other variables have no impacts.
\end{abstract}

KEYWORDS: granger analysis, shopping, earmarking, non-tax state revenue

\begin{abstract}
ABSTRAK
Sejumlah riset telah dilakukan untuk menguji pengaruh anggaran belanja terhadap pendapatan pemerintah pada level pemerintahan daerah. Sampai saat masih sedikit bukti yang mengungkapkan adanya pengaruh alokasi anggaran belanja pemerintah pusat terhadap pendapatan yang diperoleh Kementerian Negara/ Lembaga (K/ L). Riset ini bertujuan untuk mengungkapkan pengaruh alokasi anggaran terhadap realisasi Penerimaan Negara Bukan Pajak (PNBP) pada K/ L selama periode 2012-2017, sebelum pemberlakuan UU Nomor 9 Tahun 2018 tentang Penerimaan Negara Bukan Pajak. Metode pengambilan sampel yang digunakan adalah purposive sampling, diperoleh 24 instansi pemerintah sebagai objek penelitian. Dengan menggunakan analisis granger dan panel data dengan pendekatan random effect model, penelitian ini menguji pengaruh belanja barang, belanja modal, dan belanja pegawai terhadap kinerja PNBP. Hasil studi ini menyimpulkan bahwa belanja barang berpengaruh signifikan terhadap capaian realisasi PNBP pada K/ L, sementara kedua variabel belanja yang lain tidak berdampak signifikan.
\end{abstract}

KATA KUNCI: analisis granger, belanja, earmarking, penerimaan negara bukan pajak

KLASIFIKASI JEL:

H50, H72

CARA MENGUTIP:

Wibowo, P., Abimanyu, Y., Syafardi, H., Prabowo, M., \& Indrawati, I. (2021), pengaruh belanja terhadap penerimaan negara bukan pajak pada kementerian negara/ lembaga periode 2012-2017. Indonesian Treasury Review: Jurnal Perbendaharaan, Keuangan Negara, dan Kebijakan Publik, 6(3), 227-245. 


\section{PENDAHULUAN}

\section{Latar Belakang}

Pengelolaan Penerimaan Negara Bukan Pajak (PNBP) telah mengalami reformasi setidaknya sebanyak tiga kali. Pertama, peluncuran UndangUndang (UU) Nomor 20 Tahun 1997 tentang PNBP yang sekaligus menandai dimulainya pungutan PNBP lebih profesional dan akuntabel. Kedua, terbitnya UU Nomor 17 Tahun 2003 tentang Keuangan Negara yang menegaskan PNBP sebagai kelompok pendapatan yang terpisah dari pajak dan hibah dalam postur APBN. Ketiga, pemberlakuan UU Nomor 9 Tahun 2018 tentang Penerimaan Negara Bukan Pajak yang menggantikan sekaligus menyempurnakan ketentuan perundangan di bidang PNBP tahun 1997 tersebut. Reformasi PNBP telah membuahkan hasil yang sangat menggembirakan. Hal ini antara lain ditandai dengan pencapaian PNBP yang selalu di atas Rp100 triliun sejak tahun 2005. PNBP juga mengalami pertumbuhan yang cukup baik yaitu rata-rata 10,5 persen dalam kurun waktu 2005-2019. Bahkan, dalam lima tahun terakhir, kinerja pencapaian PNBP selalu mengalami kenaikan dan melampau target APBN (Grafik 1). Selama periode 2015-2019, kontribusi PNBP selalu di atas Rp250 triliun atau sekitar 15 persen dari total pendapatan negara.

Dinamika PNBP tersebut seringkali dikaitkan dengan realisasi belanja yang dikeluarkan pemerintah dalam rangka pelaksanaan pungutan PNBP. Hal ini karena di dalam UU PNBP Nomor 9 Tahun 2018 maupun UU Nomor 20 Tahun 1997 mengatur ketentuan mengenai penggunaan dana PNBP. Adanya ketentuan ini dimaksudkan agar sebagian dana PNBP dapat digunakan kembali oleh Kementerian Negara/ Lembaga selaku instansi pengelola PNBP untuk mendukung kegiatan penyelenggaraan pengelolaan PNBP dan/atau optimalisasi PNBP.

Perbedaan kedua UU tersebut dalam pengaturan penggunaan dana PNBP antara lain adalah dalam hal instansi pengguna tujuan penggunaan. Di dalam UU Nomor 20 Tahun 1997, penggunaan PNBP hanya diperkenankan untuk 6 kelompok kegiatan yaitu: (i) penelitian dan pengembangan teknologi, (ii) pelayanan kesehatan, (iii) pendidikan dan pelatihan, (iv) penegakan hukum, (v) pelayanan yang melibatkan kemampuan intelektual tertentu, dan (vi) pelestarian sumber daya alam. Sementara itu, tujuan penggunaan PNBP di dalam UU Nomor 9 Tahun 2018 bersifat lebih umum yaitu penyelenggaraan Pengelolaan PNBP, peningkatan kualitas penyelenggaraan pengelolaan PNBP, dan optimalisasi PNBP.

Apabila dikaitkan dengan perkembangan belanja $\mathrm{K} / \mathrm{L}$ dalam rangka pelaksanaan tugas dan

PENERAPAN DALAM PRAKTIK
1. Belanja barang dari DIPA-PNBP
berpengaruh positif terhadap capaian
realisasi PNBP.
2. Belanja modal dari DIPA PNBP dan belanja
pegawai DIPA RM tidak berdampak
signifikan terhadap kinerja PNBP.
3. Kebijakan penggunaan dana PNBP selama
periode tahun 2012-2017 terbukti efektif
dalam mendorong capaian PNBP.
4. Dalam rangka peningkatan kualitas layanan
berbasis PNBP, hendaknya alokasi belanja
DIPA-PNBP lebih banyak diprioritaskan untuk
belanja barang
5. Perlu dipertimbangkan skema insentif PNS
berbasis PNBP agar dapat mendorong
peningkatan kualitas layanan dan
optimalisasi PNBP.

fungsinya, pola realisasi belanja $\mathrm{K} / \mathrm{L}$ yang bersumber dari dana PNBP (DIPA-PNBP) ternyata didominasi oleh belanja barang. Realisasi belanja barang (DIPA-PNBP) sebelum diberlakukannya UU Nomor 9 Tahun 2018 yaitu dalam kurun waktu 2012-2017 secara rata-rata mencapai Rp35,42 Triliun atau 85,4\% dari pagu APBN. Meskipun pagu belanja tidak terserap secara optimal namun pencapaian PNBP ternyata melampaui target sebagaimana tersaji pada Grafik 1.

Adanya perubahan kebijakan penggunaan dana PNBP, dinamika realisasi PNBP serta belanja DIPA-PNBP di atas, , memotivasi penulis untuk melakukan analisis mengenai seberapa jauh peranan belanja K/ L selama ini dalam mendukung upaya optimalisasi PNBP. Dengan kata lain, penelitian ini hendak mengamati hubungan kausalitas antara belanja dengan pencapaian realsiasi PNBP K/L, khususnya dalam periode sebelum terbitnya UU PNBP Nomor 9 Tahun 2018. Penelitian yang mengungkapkan adanya berbagai hubungan antara pendapatan dan pengeluaran pemerintah dapat kita jumpai pada beberapa literatur seperti Aminu \& Raifu (2019), Ghazo \& Abu-Lila (2018), Abdulrasheed (2017), Sere \& Choga (2017), Ullah (2017), Saysombath \& Kyophilavong (2013), Al-Khulaifi (2012), Subhani et al. (2012) dan Mehrara et al. (2011). Bahkan, penelitian sejenis telah juga dilakukan sebelum dasa warsa ini, antara lain Taha \& Loganathan (2008), Gounder et al. (2007), Narayan \& Narayan (2006).

Khusus di Indonesia, penelitian mengenai faktor determinan pendapatan pemerintah, khususnya pemerintah daerah di Indonesia dapat kita jumpai antara lain pada Sani et al. (2018), Iswari (2018), Deswantoro, et al. (2017), Nurhaeni (2016), Puspitasari et al. (2015), Darwis (2015) 
Grafik 1: Perkembangan PNBP 2015-2019

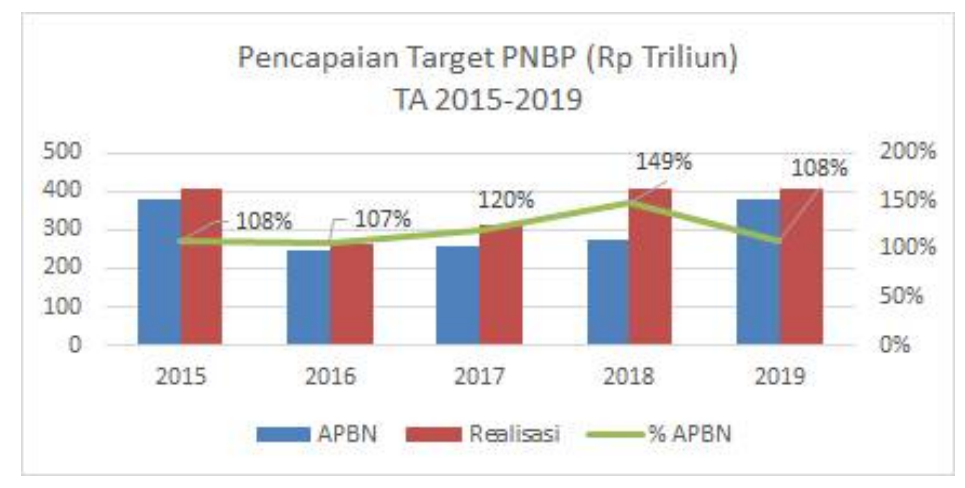

Sumber: LKPP 2015-2019 (audited)

Darwanis \& Saputra (2014), Heryana (2014), dan Astiti \& Mimba (2016). Penelitian mereka berupaya mengungkapkan dampak sejumlah kelompok belanja dalam Anggaran Pendapatan dan Belanja Daerah (APBD) terhadap pertumbuhan ekonomi, pendapatan asli daerah, ekuitas dana, maupun SILPA (Sisa Lebih Pembiayaan Anggaran). Hasil penelitian mereka belum memberikan konklusi yang seragam terkait dampak belanja terhadap kinerja keuangan maupun parameter ekonomi daerah.

Sebaliknya, penelitian mengenai determinan PNBP di Indonesia belum banyak dijumpai di sejumlah literatur. Beberapa penelitian yang dihasilkan hampir seluruhnya menggunakan pendekatan studi kasus. Penelitian tersebut Asriyanti (2018), Sari (2017), Walelang et al. (2017), Taswin (2015), Rosdiana (2010 dan 2013) dan Jaya (2011). Namun demikian, berbagai penelitian tersebut belum ada yang secara langsung membahas dampak belanja instansi pemerintah pusat terhadap kinerja PNBP dalam bentuk analisis lintas $\mathrm{K} / \mathrm{L}$ dan tahun (panel data analysis). Oleh karena itu, penelitian ini berupaya mengisi gap penelitian dengan menghadirkan bukti empiris yang baru, Riset ini bertujuan untuk menganalisis pengaruh belanja barang, belanja modal dan belanja pegawai terhadap kinerja PNBP pada K/L pada periode 2012-2017. Penelitian ini diharapkan memberikan kontribusi bagi pengambil keputusan di bidang anggaran pemerintah pusat dalam rangka mengevaluasi efektivitas belanja $\mathrm{K} / \mathrm{L}$ di masa lampau. Dalam perspektif akademik, riset ini memberikan jalan bagi penelitian kuantitatif di bidang PNBP dengan memberikan bukti empiris mengenai urgensi alokasi belanja dalam optimalisasi PNBP.

\section{STUDI LITERATUR}

\section{Kerangka Teori}

Pemerintah kabupaten/ kota dapat menggunakan fees atau user charges sebagai sumber keuangan alternatif guna mengurangi pengeluaran atau menghasilkan pendapatan (Cui 2013). Biaya dan ongkos pengguna telah dikembangkan dalam beragam definisi. Dalam istilah yang paling sederhana, fees dan user charges adalah harga yang ditentukan oleh pemerintah untuk barang dan jasa yang mereka sediakan (Mercer \& Morgan, 1983). Di Indonesia fees dan user charges tersebut lebih dikenal sebagai retribusi pada tingkat pemda dan PNBP untuk pemerintah pusat.

Pembebanan pungutan kepada masyarakat atas layanan pemerintah pusat telah diatur di dalam Undang-Undang mengenai PNBP. Salah satu ketentuan yang menarik di dalam UU 20/1997 tersebut adalah bahwa instansi pemerintah yang memungut PNBP dapat menggunakan sebagian dana untuk pelaksanaan kegiatan yang terkait dengan pungutan PNBP. Ketentuan ini dipertegas dan diperjelas di dalam UU Nomor 9 Tahun 2018 yang merupakan UU pengganti dari UU 20/ 1997.

Di dalam ketentuan pasal 33 UU Nomor 9 Tahun 2018, disebutkan bahwa penggunaan sebagian dana PNBP dapat diusulkan oleh K/L untuk penyelenggaraan pengelolaan PNBP dan/atau peningkatan kualitas penyelenggaraan pengelolaan PNBP, kegiatan lainnya; dan/atau optimalisasi PNBP. Menteri Keuangan memberikan persetujuan atau penolakan atas usulan tersebut dengan mempertimbangkan kondisi keuangan negara, kebijakan fiskal, dan kebutuhan pendanaan K/L. Dalam hal ini yang dimaksud dengan kebutuhan pendanaan $\mathrm{K} / \mathrm{L}$ adalah kebutuhan pendanaan K/L sebagai instansi pengelola PNBP untuk pelayanan PNBP sebagai prioritas utama. Jenis PNBP yang dapat digunakan menurut UU Nomor 9 Tahun 2018 tentang Penerimaan Negara Bukan Pajak maupun PP Nomor 58 Tahun 2020 tentang Pengelolaan Penerimaan Negara Bukan Pajak tidak lagi terbatas pada kegiatan tertentu sebagaimana pengaturan sebelumnya di dalam UU Nomor 20 Tahun 1997. Dengan demikian, sepanjang PNBP dipungut dari pelaksanaan tugas 


\section{0}

dan fungsi $\mathrm{K} / \mathrm{L}$ termasuk di dalamnya pelayanan yang dilaksanakan oleh Badan Layanan Umum dan pemanfaatan BMN, pada prinsipnya dapat digunakan sepanjang disetujui oleh Menteri Keuangan.

Berdasarkan ketentuan pasal 33 UU Nomor 9 Tahun 2018 dimaksud, besar kecilnya realisasi PNBP dapat dipengaruhi oleh sejauh mana efektivitas penggunaan dana PNBP oleh $\mathrm{K} / \mathrm{L}$. Kebijakan pungutan dan penggunaan dana PNBP untuk kegiatan layanan PNBP dapat dipandang dari berbagai perspektif. Pertama, penggunaan dana PNBP merupakan praktik earmarking yang diperkenalkan oleh Buchanan (1963). Earmarking merupakan praktik untuk mendedikasikan sumber pendapatan tertentu guna dialokasikan dalam pendanaan kegiatan layanan publik. Kebijakan earmarking tersebut bertujuan untuk memberikan kepastian sumber pendanaan atas kegiatan tertentu. Di Indonesia, kebijakan earmarking bertujuan untuk melindungi program-program prioritas tertentu dari pergeseran oleh program prioritas lain (Kurniasih, 2016).

Kedua, dari literatur keuangan publik dan pilihan publik. Pungutan PNBP menunjukkan bahwa birokrasi pemerintah itu tidak efisien karena birokrat dapat mengeksploitasi posisi monopoli mereka untuk memaksa warga selaku konsumen ke dalam kurva permintaan dengan skema pembebanan semuanya ke warga atau dibebaskan sama sekali (Sun, 2009).

Ketiga, kebijakan pengelolaan PNBP dapat dipandang sebagai upaya untuk memaksimalkan ukuran anggaran organisasi mereka, terutama "diskresi anggaran ," dengan biaya warga negara (Niskanen, 1975). Pandangan ini dikenal luas sebagai budget maximizing theory. Mengikuti teori ini, Downing (1984) mengemukakan bahwa jika konsumen tidak memiliki informasi yang baik tentang kegiatan birokrat, pemerintah akan menghasilkan barang dan jasa publik dengan jumlah yang lebih besar dari skala efisien dan dengan biaya yang lebih tinggi dari biaya efisien.

Keempat, perilaku birokrasi terkait pengelolaan keuangan dapat dilihat dari teori "ilusi fiskal (Sun, 2009). Teori ini menunjukkan bahwa ketika pendapatan pemerintah tidak diamati atau tidak sepenuhnya diamati oleh pembayar pajak, biaya pemerintah dianggap lebih murah daripada yang sebenarnya. Dengan demikian, dari perspektif politisi, keberadaan ilusi fiskal memungkinkan politisi untuk memilih mekanisme pendapatan yang memaksimalkan sejauh mana pengeluaran bisa ditingkatkan tanpa menarik perhatian publik. Sementara itu pada saat yang sama, mekanisme pendapatan yang seperti ini akan cenderung mendorong konsumsi yang lebih besar dari titik optimal pembayar pajak dengan menyembunyikan fakta mengenai biaya actual dari pelayanan publik (Wagner, 1976 dalam Sun 2009).

Kelima, teori keagenan juga dapat digunakan untuk menjelaskan perilaku birokrat terkait penganggaran. Menurut Jensen \& Meckling (1976) hubungan keagenan sebagai kontrak di mana satu atau lebih orang (principal) melibatkan orang lain (agen) untuk melakukan beberapa layanan atas nama mereka yang melibatkan pendelegasian wewenang pengambilan keputusan kepada agen. Jika kedua pihak melakukan hubungan adalah pemaksimal utilitas, ada alasan kuat untuk meyakini bahwa agen tidak akan selalu bertindak yang terbaik kepentingan principal. Kebijakan penggunaan dana PNBP memberikan peluang bagi birokrat untuk mengusulkan anggaran yang tidak berkaitan langsung dengan layanan berbasis PNBP.

\section{Penelitian Terdahulu}

Hubungan kausal antara penerimaan dan pengeluaran pemerintah merupakan masalah klasik ekonomi publik. Terdapat empat proposisi yang berpotensi dapat menjelaskan perilaku pengeluaran-pendapatan (Mehrara, et al. 2011). Proposisi pertama, tax and spend yang diindikasikan oleh Friedman (1978) bahwa menaikkan pajak hanya akan menghasilkan lebih banyak pengeluaran.

Kelompok kedua berpendapat adanya skema spend and tax. Prinsip ini memandang bahwa pengeluaran menghasilkan pendapatan (Peacock \& Wiseman, 1961). Mereka menyatakan bahwa peningkatan pengeluaran pemerintah yang disebabkan oleh situasi krisis menyebabkan perubahan permanen dalam pengeluaran. Mereka berpandangan bahwa krisis parah yang awalnya memaksa pengeluaran pemerintah, lebih dari pajak, mampu mengubah sikap publik tentang ukuran pemerintahan yang tepat. Hal ini menyebabkan pergeseran variabel fiskal karena beberapa kenaikan pajak yang semula dibenarkan oleh situasi krisis menjadi kebijakan pajak permanen (Narayan \& Narayan, 2006).

Pandangan ketiga, fiscal synchronization, yang menyakan bahwa pemerintah dapat mengubah pengeluaran dan pajak secara bersamaan (Meltzer \& Richard, 1981; Musgrave, 1966). Hal ini menyiratkan kausalitas dua arah antara pengeluaran pemerintah dan pendapatan. Di bawah hipotesis sinkronisasi fiskal, warga negara memutuskan tingkat pengeluaran dan pajak. Hal ini dilakukan dengan membandingkan manfaat pemerintah dengan biaya marjinal warga, (Narayan \& Narayan, 2006).

Perspektif yang keempat adalah fiscal neutrality. Dalam hipotesis ini, pemerintah 
dianggap dapat melakukan penyesuaian pengeluaran dan pendapatan (Meltzer \& Richard, 1981; Musgrave, 1966). Hal ini menyiratkan kausalitas dua arah antara pengeluaran pemerintah dan pendapatan.

Studi tentang korelasi antara pendapatan dengan pengeluaran pemerintah antara lain telah memberikan bukti adanya dampak positif pengeluaran pemerintah dan pendapatan pemerintah. Hubungan jangka panjang antara pendapatan dan pengeluaran pemerintah di Afrika Selatan telah ditemukan oleh Sere \& Choga (2017). Penelitian ini sekaligus memperkuat riset sebelumnya di Laos yang dilakukan oleh Saysombath \& Kyophilavong (2013) dan penelitian oleh Mehrara et al. (2011) atas sejumlah negara Asia serta Magazzino (2014) pada ASEAN-6 dan ASEAN10. Sementara itu Ghazo \& Abu-Lila (2018) menemukan adanya pengaruh positif pengeluaran pemerintah terhadap pendapatan pajak di Jordania. Hasil ini mengkonfirmasi riset sebelumnya yang dilakukan oleh Abdulrasheed (2017) dalam penelitiannya di Nigeria. Hubungan dua arah antara pendapatan dan pengeluaran negara juga ditemukan selama periode 1963-2017 di Indonesia (Sani et al. 2018). Sejumlah penelitian di atas menggunakan pendekatan kausalitas Granger.

Sementara itu riset mengenai korelasi antara biaya penyelenggaraan layanan publik dengan pendapatan pemerintah di luar pajak, baik berupa fees maupun user charges telah dilakukan oleh beberapa peneliti terdahulu. Sun \& Jung (2011) mengamati pengaruh ketergantungan user charges terhadap biaya yang dikeluarkan untuk pemberian layanan publik pada 686 kota di Amerika selama kurun waktu 1972-2004. Hasil riset menyimpulkan bahwa tingkat ketergantungan terhadap user charges yang lebih besar pada saluran pembuangan dan taman dan layanan rekreasi menghasilkan tingkat pengeluaran yang lebih rendah untuk layanan yang dibiayai oleh user charges tersebut. Hal senada juga telah diungkapkan sebelumnya antara lain oleh (Bierhanzl \& Downing, 2004; Jung \& Bae, 2011).

Borge \& Rattsø (2003) melakukan analisis hubungan antara biaya dan user charges untuk saluran pembuangan di tingkat pemda di Norwegia selama kurun waktu 1993-1998. Hasil penelitiannya menyatakan bahwa sekitar 40\% dari kenaikan biaya diteruskan ke konsumen dalam hal user charges yang lebih tinggi. Selain itu, user charges memiliki efek negatif yang signifikan pada biaya per unit layanan. Peningkatan tingkat pembiayaan biaya pengguna sebesar 0,1 poin diprediksi akan mengurangi biaya unit sebesar 5$8 \%$.

Penelitian mengenai determinan pendapatan maupun kinerja keuangan pemerintah daerah (sub- national governments) di Indonesia lebih banyak menggunakan alokasi belanja yang bersumber dari general fund atau non-earmarked budget. Dengan kata lain belanja yang direncanakan dalam APBD tidak mensyaratkan adanya koneksi langsung antara pagu belanja dengan besaran pendapatan daerah. Secara umum, komponen belanja yang terbukti secara empiris memberikan dampak positif terhadap kinerja keuangan pemerintah daerah adalah belanja modal (Iswari 2018, Deswantoro, et al., 2017, Darwis 2015 Puspitasari et al., 2015, Heryana, 2014, dan Darwanis \& Saputra 2014).

Sebaliknya, belanja barang dan belanja pegawai justru memberikan fenomena yang lebih menarik. Astiti \& Mimba (2016) dalam penelitiannya terhadap sembilan kabupaten/kota di Provinsi Bali menemukan bahwa belanja rutin (yang antara lain terdiri dari belanja pegawai dan barang) tidak berpengaruh signifikan terhadap kinerja keuangan daerah. Penelitian tersebut memperkuat hasil riset Nurhaeni (2016) yang mengungkapkan bahwa belanja barang dan jasa tidak berdampak pada ekuitas dana. Sementara Deswantoro et al. (2017) justru menemukan pengaruh negatif belanja barang terhadap pertumbuhan ekonomi di Sulawesi Barat. Adapun pengaruh positif belanja barang antara lain ditemukan oleh Patriati (2010).

Lokus penelitian tersebut di atas adalah pemerintah daerah sementara riset ini berfokus pada instansi pemerintah pusat. Penelitian mengenai faktor determinan PNBP telah dilakukan oleh beberapa peneliti di Indonesia seperti Sari (2017), Walelang et al. (2017), Taswin (2015), Jaya (2011), dan Kurniasih (2016). Namun demikian, penelitian tersebut masih berfokus pada satu instansi $\mathrm{K} / \mathrm{L}$ (studi kasus) dan belum ada yang membahas kinerja PNBP lintas K/L. Sari (2017) meneliti pengaruh kinerja PNBP pada Kementerian Agraria selama kurun waktu 2012-2016. Walelang et al. (2017) membahas pengendalian internal pengelolaan PNBP di Kantor Lelang Manado. Jaya (2011) menganalisis pengaruh motivasi pegawai terhadap akuntabilitas pengelolaan PNBP pada Universitas Syah Kuala Aceh.

\section{Pengembangan Hipotesis}

Berdasarkan kerangka teori dan hasil penelitian terdahulu, hipotesis yang dikembangkan dalam penelitian kami dapat dijabarkan sebagai berikut.

\section{Belanja Barang}

Di dalam ketentuan pasal 33 UU Nomor 9 Tahun 2018 tentang PNBP disebutkan bahwa penggunaan dana PNBP dimaksudkan untuk penyelenggaraan pengelolaan PNBP dan/atau peningkatan kualitas penyelenggaraan pengelolaan PNBP dan/ atau kegiatan lainnya; dan optimalisasi 


\section{2}

PNBP. Ketentuan tersebut mempertegas pengaturan di dalam dasar hukum sebelumnya, yaitu UU Nomor 20 Tahun 1997. Oleh karena itu, apabila K/L melakukan penyerapan anggaran belanja barang secara efektif, akan berdampak positif terhadap kinerja layanan publik. Kinerja layanan yang baik pada akhirnya berimbas pada pencapaian realisasi PNBP sesuai tugas dan fungsi. Hal ini sejalan dengan spend-tax hypothesis sebagaimana dikemukakan oleh Peacock \& Wiseman (1961,). Sebelum terbitnya UU Nomor 9 Tahun 2018, PNBP yang diperoleh sesuai pelaksanaan tugas dan fungsi disebut sebagai PNBP fungsional. Sebaliknya, PNBP yang diperoleh di luar tugas dan fungsi seperti pengembalian belanja tahun anggaran yang lalu, merupakan PNBP nonfungsional (PNBP umum). Dikotomi istilah PNBP fungsional dan non-fungsional tidak lagi digunakan setelah berlakunya UU Nomor 9 Tahun2018.

Salah satu pengeluaran negara yang dipandang memberikan efek langsung bagi penyelenggaraan layanan publik adalah belanja barang dan jasa. Belanja ini sering dikelompokkan ke dalam belanja rutin. Astiti \& Mimba (2016) menyatakan bahwa belanja rutin pada dasarnya berlaku untuk satu tahun periode anggaran. Dalam rangka memberikan pelayanan kepada publik, pemerintah melakukan pengeluaran belanja rutin. Dengan mempertimbangkan hasil penelitian mengenai hubungan dua arah antara pendapatan dan pengeluaran yang antara lain disampaikan oleh Magazzino (2014) Mehrara et al. (2011), dan Sani et al. (2018), hipotesis riset terkait belanja barang adalah:

Hipotesis 1 : terdapat hubungan kausalitas Granger antara belanja barang PNBP dan PNBP fungsional.

\section{Belanja Modal}

Belanja modal sesuai ketentuan Peraturan Menteri Keuangan Nomor 102/ PMK.02/ 2018 tentang Klasifikasi Anggaran pada prinsipnya merupakan belanja untuk pengadaan peralatan dan mesin yang digunakan langsung dalam proses layanan publik. Oleh karena itu, apabila K/ L melakukan penyerapan anggaran belanja modal secara efektif, akan berdampak positif terhadap kinerja PNBP fungsional. Darwis (2015) menyatakan bahwa belanja modal digunakan untuk memperoleh keuntungan pada masa yang akan datang sesuai dengan masa manfaat ekonomis aktiva yang bersangkutan. Oleh sebab itu, perhitungan antara biaya yang dikeluarkan dan manfaat yang akan diperoleh harus dapat diperbandingkan.

Sesuai dengan hasil penelitian terdahulu yang menyatakan belanja modal berdampak positif terhadap berbagai indikator keuangan daerah (Iswari 2018, Deswantoro, et al.. 2017, Nurhaeni 2016, Puspitasari et al.. 2015, Darwis 2015, dan Darwanis \& Saputra 2014), maka belanja modal diharapkan dapat menstimulus pemungutan PNBP dari layanan yang diselenggarakan oleh $\mathrm{K} / \mathrm{L}$. Memperhatikan hasil penelitian mengenai hubungan dua arah antara pendapatan dan pengeluaran yang antara lain disampaikan oleh Magazzino (2014) Mehrara et al. (2011) dan Sani, et al. (2018), hipotesis riset terkait belanja modal adalah:

Hipotesis 2 : terdapat hubungan kausalitas Granger antara belanja modal PNBP dan PNBP fungsional

Belanja Pegawai

Sesuai ketentuan PMK Nomor 102/PMK.02/2018, belanja pegawai merupakan kompensasi terhadap pegawai baik dalam bentuk uang maupun dalam bentuk barang, yang harus dibayarkan kepada pegawai Pemerintah dalam dan luar negeri, baik kepada Pejabat Negara, Pegawai Negeri Sipil (PNS) dan pegawai yang dipekerjakan oleh Pemerintah yang belum berstatus PNS dan/ atau non-PNS sebagai imbalan atas pekerjaan yang telah dilaksanakan dalam rangka mendukung tugas fungsi unit organisasi Pemerintah. Deswantoro, et al. (2017) menemukan bahwa belanja pegawai berdampak positif terhadap perekonomian daerah. Oleh karena itu hipotesis yang dikembangkan dalam penelitian ini adalah:

Hipotesis 3 : terdapat hubungan kausalitas Granger antara belanja pegawai dan PNBP fungsional

\section{METODOLOGI PENELITIAN}

Penelitian ini merupakan riset kuantitatif kausalitas yang menggunakan regresi linear berganda dengan memakai data panel lintas $\mathrm{K} / \mathrm{L}$ dalam beberapa tahun pengamatan melalui pendekatan kausalitas Granger dan analisis panel. Populasi dalam penelitian ini adalah seluruh K/L yang merupakan instansi pengelola PNBP. Periode waktu yang diamati adalah lima tahun sebelum terbitnya UU Nomor 9 Tahun 2018, yaitu tahun 2012-2017. Pemilihan periode ini dilakukan mengingat pada periode tersebut, pengelolaan PNBP masih menggunakan UU Nomor 20 Tahun 1997 beserta produk hukum turunannya. Penelitian sejenis untuk periode setelah berlakunya UUNomor 9 Tahun 2018 akan menjadi area riset yang baru bagi penelitian selanjutnya.

Jenis dan Sumber Data 
Pengambilan sampel penelitian dilakukan dengan menggunakan metode purposive sampling dengan kriteria sebagai berikut:

a. K/ L telah mempunyai PP atau pun PMK yang mengatur jenis dan tarif atas jenis PNBP dan memperoleh ijin penggunaan sebagian dana PNBP dalam bentuk Keputusan Menteri Keuangan sejak awal tahun pengamatan, yaitu 2012.

b. K/ L menyajikan data yang lengkap mengenai realisasi PNBP fungsional, realisasi belanja barang PNBP, belanja modal PNBP dan belanja pegawai selama periode 2012-2017 dalam LRA.

c. K/L tidak mengalami pemekaran maupun penggabungan sebagai akibat terbentuknya pemerintahan baru pada akhir 2014.

Data yang digunakan dalam penelitian ini adalah data sekunder. Data dimaksud antara lain berupa Laporan Hasil Pemeriksaan BPK-RI atas Laporan KeuanganK/ L dari tahun 2012-2017. Data tersebut diperoleh langsung dari Pusat Informasi dan Komunikasi BPK-RI. Penelitian ini tidak memasukkan BPK-RI sebagai objek penelitian karena laporan keuangannya diaudit oleh Kantor Akuntan Publik (KAP). Penulis juga memperoleh data sekunder lainnya berupa realisasi belanja K/ L dan realisasi PNBP masing-masing dari Direktorat Jenderal Perbendaharaan dan Direktorat Jenderal Anggaran. Peneliti hanya melakukan pengamatan terhadap data sekunder yang diperoleh. Dengan demikian, peneliti tidak melakukan wawancara kepada para pejabat atau pegawai yang terlibat dalam pengelolaan PNBP.

\section{Definisi Operasional Variabel}

Variabel dependen dalam penelitian ini adalah realisasi PNBP fungsional (PNBPFung). Angka PNBP fungsional yang digunakan sebagai pengukuran dalam model penelitian ini adalah berupa realisasi PNBP fungsional dibagi dengan total aset. Yang dimaksud dengan PNBP fungsional dalam penelitian ini adalah PNBP yang dihasilkan dari pelayanan kepada lapisan masyarakat, dimana jenis dan tarif atas layanan tersebut sudah ditetapkan dalam PP atau dalam Peraturan Menteri Keuangan (khusus layanan BLU). Oleh karena itu, PNBP umum yang diperoleh dari pemanfaatan aset seperti pendapatan sewa, penjualan barang lelang, maupun pendapatan dari pengembalian belanja tahun anggaran yang lalu, tidak masuk dalam kategori PNBP fungsional.

Operasionalisasi variabel PNBP fungsional adalah berupa realisasi PNBP fungsional $\mathrm{K} / \mathrm{L}$ dibagi dengan total aset masing-masing K/ L. Penggunaan total aset yang dimiliki Kementerian/Lembaga dalam pengukuran variabel mampu membedakan kekuatan yang dimiliki Kementerian/Lembaga tersebut (Agusti et al., 2014). Kekuatan tersebut dapat berupa rentang kendali K/ L (terpusat atau tersebar), sumber daya manusia, maupun banyaknya stakeholders yang dilayani. Total asset merupakan salah satu proxy yang mencerminkan ukuran K/L. Realisasi PNBP yang dibagi dengan total aset diharapkan dapat mencerminkan keragaman K/ L berdasarkan ukuran tersebut.

Variabel independen dalam penelitian ini adalah realisasi belanja barang PNBP (BelBrg), belanja modal PNBP (BelMod), dan belanja pegawai (BelPeg) yang disajikan dalam LRA K/L selama periode pengamatan. Belanja barang dan belanja modal dalam penelitian ini adalah belanja yang sumber dananya berasal dari PNBP fungsional (DIPA-PNBP). Dana tersebut diperoleh dari pungutan PNBP yang diperoleh dari masyarakat atas penyelenggaraan layanan publik. Operasionalisasi variabelnya berupa realisasi masing-masing belanja dibagi total aset. Demikian juga untuk belanja pegawai (DIPA-RM) diukur dengan menggunakan perbandingan antara realisasi belanja pegawai dengan total aset K/ Lyang bersangkutan. Penggunaan total aset yang dimiliki $\mathrm{K} / \mathrm{L}$ dalam pengukuran variabel mampu membedakan kekuatan yang dimiliki $\mathrm{K} / \mathrm{L}$ tersebut (Agusti et al., 2014).

\section{Metode Analisis Data}

Teknik analisis data dengan menggunakan model persamaan panel causality secara Granger dalam penelitian ini dikembangkan melalui beberapa tahapan berikut

\section{a. Pengujian panel unit root}

Pengujian unit root dilakukan untuk memastikan apakah data yang digunakan merupakan data yang bersifat stasioner. Sekumpulan data dinyatakan stasioner jika nilai rata-rata dan varian dari data time series tersebut tidak mengalami perubahan secara sistematik sepanjang waktu, (Gujarati 2003). Data yang tidak stasioner dapat menyebabkan model yang diestimasi kurang valid.

Dalam penelitian ini, unit root test yang digunakan adalah Im et al. (2003), (selanjutnya disebut IPS), dan Levin et al. (2002), (selanjutnya disebut LLC). Pengujian ini dinilai dapat memberikan hasil yang lebih baik untuk data panel dibandingkan data time series untuk setiap individu yang diobservasi (Levin et al., 2002).

\section{b. Pendekatan panel cointegration}

Kointegrasi menunjukkan adanya hubungan jangka panjang antar variabel yang diamati (Gujarati, 2003). Jika dua deret waktu masingmasing bersifat nonstasioner, tetapi beberapa kombinasi linier di antaranya merupakan proses 


\section{4}

stasioner, maka kedua deret waktu tersebut dikatakan berkointegrasi. Deret waktu dikatakan stasioner kovarian jika mean, varians, dan kovariannya semuanya invarian terhadap waktu, dalam hal ini ia terintegrasi dari orde nol, atau I (0).

Pada penelitian ini, kami menerapkan uji kointegrasi panel, uji tipe DF dan ADF yang diajukan oleh Kao (1999) untuk hipotesis nol tentang tidak adanya kointegrasi dalam panel homogen dan heterogenity.

\section{c. Pengujian hipotesis}

Di dalam riset ini, peneliti melakukan uji kausalitas Granger. Hal ini dimaksudkan untuk mengetahui apakah terdapat hubungan timbal balik antara belanja dengan capaian realisasi K/ L. Engle \& Granger (1987) menunjukkan bahwa jika dua variabel non-stasioner berkointegrasi, vector autoregression (VAR) pada perbedaan pertama akan salah dispesifikasikan. Jika ditemukan hubungan ekuilibrium jangka panjang antara pendapatan PNBP dan belanja pemerintah saat menguji kausalitas Granger, kita perlu menentukan model dengan representasi koreksi kesalahan dinamis. Ini berarti bahwa model VAR tradisional ditambah dengan istilah koreksi kesalahan tertinggal satu periode yang diperoleh dari model kointegrasi (Vector Error Correction Model-VECM).

Uji kausalitas Granger dalam riset ini mengadopsi penelitian Mehrara, Pahlavani, dan Elyasi (2011) dengan model regresi berikut ini:

$\triangle P N B P F u n g$ i,t $=\sum \alpha_{1} \triangle P N B P F u n g$ it-p $+\sum \beta_{1} \Delta$ belBrg it-p $+{ }_{1} \triangle E C T$ it $1+\alpha$ i,t ............................................. (1)

$\triangle B e l B r g$ i,t $=\sum \alpha_{2} \triangle P N B P F u n g$ it-p $+\sum \beta_{2} \Delta b e l B r g_{i t-p}+$ $\gamma_{2} \Delta E C T$ it- $+\alpha$ i,t

$\triangle P N B P F u n g$ i,t $=\sum \alpha_{3} \triangle P N B P F u n g$ it $p+\sum \beta_{3} \triangle$ belMod it-p $+{ }_{3} \triangle E C T$ it- $1+\alpha$ i,t

$\triangle$ BelMod $_{\mathrm{i}, \mathrm{t}}=\sum \alpha_{4} \triangle P N B P F u n$ it-p $+\sum \beta_{4} \Delta$ belMod it-p + $\gamma_{4} \triangle E C T$ it- $1+\alpha_{\text {i,t }}$

$\triangle P N B P F u n g$ i,t $=\sum \alpha_{5} \triangle P N B P F u n g$ it $-\mathrm{p}+\sum \beta_{5} \Delta$ belPeg it-p $+\gamma_{5} \triangle E C T$ it $-1+\alpha$ i,t

$\triangle B e l P e g$ i,t $=\sum \alpha_{6} \triangle P N B P F u n g$ it-p $+\sum \beta_{6} \Delta b e l P e g$ it-p + $\gamma_{6} \Delta \mathrm{ECT}$ it- $1+\alpha$ i,t

Simbol ' $\Delta$ ' menunjukkan first-difference variable, ECT merupakan error correction term dan 'p' menunjukkan panjang lag. ECT juga merupakan estimasi residual dari model jangka panjang dalam Persamaan (1) s.d. (6), sementara koefisien y pada ECT mencerminkan hubungan ekuilibrium jangka panjang di antara variabel yang diamati. Apabila data dalam penelitian ini terkointegrasi pada level, maka uji kausalitas dapat menggunakan model VAR. Sebaliknya jika data terkointegrasi pada level firstdifference, model VECM sebagaimana persamaan
(1) dan (6) akan digunakan. Jika $\alpha_{i}=0$ dan $\beta_{i}=0$, tidak terdapat hubungan timbal balik diantara variabel realisasi PNBP dan belanja K/ L. Sebaliknya jika $\alpha_{i} \neq 0$ dan $\beta_{i} \neq 0$, terjadi hubungan kausalitas diantara variabel independen dengan variabel dependen (bi-directional). Jika salah satu koefisien $\alpha \mathrm{i}$ atau $\beta \mathrm{i}$ tidak sama dengan nol, maka terjadi hubungan satu arah (uni direction).

Untuk mengkonfirmasi hasil Granger causality, kami juga akan melakukan analisis panel. Hipotesis untuk panel data ini masing-masing berupa adanya pengaruh positif belanja barang (DIPA-PNBP), belanja modal (DIPA-PNBP) dan belanja pegawai (DIPA-RM) terhadap realisasi PNBP pada instansi pengelola PNBP. Model persamaan regresi linear (panel analysis) yang dikembangkan dalam penelitian ini berasal dari hasil adopsi model Gounder et al. (2007) sebagaimana yang telah digunakan dalam model penelitian Narayan \& Narayan (2006) sebagai berikut:

$$
\mathrm{GR}_{\mathrm{t}}=\alpha+\beta \mathrm{GE}_{\mathrm{t}}
$$

GR merepresentasikan government revenue dan GE mewakili government expenditure. Dalam model penelitian di atas, Gounder et al. (2007) menggunakan sejumlah komponen pengeluaran pemerintah untuk diregresikan dengan total pendapatan agregat pemerintah

Berdasarkan model penelitian di atas, dalam kontek analisis pengaruh alokasi belanja pemerintah pusat terhadap capaian realisasi PNBP, penelitian ini menggunakan persamaan sebagai berikut:

PNBPFung $_{i, t}=\alpha+\theta_{1}$ BelBrg $i, t+\theta_{2}$ BelMod i,t + $\theta_{3}$ BelPeg i,t $+\alpha \mathrm{i}, \mathrm{t}$.

\section{Keterangan:}

PNBPFung i,t : Realisasi PNBP fungsional dibagi dengan total aset $\mathrm{K} / \mathrm{L}$

BelBrg $i$, : Penyerapan/ realisasi belanja barang (DIPA PNBP) dibagi dengan total aset K/ L

BelMod $_{i, t} \quad$ : Penyerapan/ realisasi belanja modal (DIPA PNBP) dibagi dengan total aset $\mathrm{K} / \mathrm{L}$

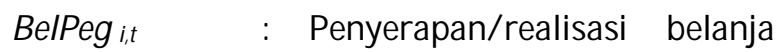
pegawai (DIPA RM) dibagi dengan total aset K/ L

Di dalam catatan atas laporan keuangan $\mathrm{K} / \mathrm{L}$ tidak banyak dijumpai rincian mengenai PNBP fungsional. Oleh karena itu, PNBP fungsional di dalam riset ini menggunakan proxy perhitungan berdasarkan pemahaman peneliti mengenai tugas dan fungsi utama dari K/ L. Tugas utama inilah yang merepresentasikan jenis PNBP fungsional pada K/ L tersebut. Secara umum, pendapatan PNBP yang dilaporkan dalam LRA K/L dan dihitung sebagai 
PNBP fungsional antara lain berupa pendapatan layanan barang dan jasa dan pendapatan BLU. Dalam hal laporan keuangan K/ L tidak menyajikan rincian pendapatan layanan barang dan jasa, peneliti menggunakan pendekatan negative list. Pendekatan ini dilakukan dengan cara mengurangkan PNBP umum dari total PNBP K/ L. PNBP umum yang dimaksud antara lain pendapatan bunga (di luar BLU), pendapatan denda, dan pengembalian belanja tahun anggaran yang lalu. Pendapatan tersebut dijumpai di semua K/ L dan tidak diperoleh dari pelaksanaan tugas dan fungsi utama K/ L.. Oleh karena itu, pendapatan PNBP umum ini dikeluarkan dari penghitungan PNBP fungsional. Khusus untuk pendapatan bunga BLU disajikan sebagai pendapatan BLU lainnya sehingga tidak termasuk dalam kelompok PNBP umum.

Selanjutnya, dalam melakukan regresi data panel, hal pertama yang dilakukan adalah melakukan pengujian untuk memilih model estimasi yang tepat untuk regresi data panel. Peneliti akan melakukan Chow test, Hausman test, dan Lagrange Multiplier test untuk memilih apakah model yang dipergunakan berupa fixed effect, random effect, atau common effect. Langkah berikutnya adalah pengujian hipotesis mengenai pengaruh belanja terhadap PNBP. Pengujian hipotesis tersebut dilakukan dengan F-test. t-test, dan uji koefisien determinasi

\section{HASIL PENELITIAN \\ Hasil}

Populasi data penelitian merupakan seluruh $\mathrm{K} /$ L yang menjadi instansi pengelola PNBP. Adapun yang dijadikan sampel dalam penelitian adalah K/ L yang memenuhi kriteria sebagaimana dimaksud pada bagian metodologi penelitian. Berdasarkan kriteria pemilihan sampel tersebut, diperoleh jumlah $\mathrm{K} / \mathrm{L}$ yang memenuhi kriteria tersebut sebanyak 24 instansi pemerintah pusat yang diamati dalam periode 6 tahun. Oleh karena itu, secara keseluruhan jumlah observasi yang diamati adalah 144 (Tabel 1)

Tabel 1. Hasil Pemilihan Sampel

\begin{tabular}{lc}
\hline Kriteria & Jumlah K/ L \\
\hline $\begin{array}{l}\text { Jumlah K/ L penghasil PNBP sesuai } \\
\text { tugas fungsi (di luar BPK) }\end{array}$ & 49 \\
$\begin{array}{l}\text { Dikurangi: K/ L yang datanya tidak } \\
\text { lengkap }\end{array}$ & $(18)$ \\
$\begin{array}{l}\text { Dikurangi: K/ L yang mengalami } \\
\text { pemekaran dan penggabungan }\end{array}$ & $(7)$ \\
Jumlah K/ L & 24 \\
Jumlah pengamatan (24x6) & $\mathbf{1 4 4}$ \\
\hline
\end{tabular}

Sumber: hasil olahan

Berdasarkan analisis korelasi antarvariabel bebas, yaitu BelBrg, BelMod, dan BelPeg, diperoleh hasil bahwa tidak ditemukan korelasi diantara mereka. Hal ini karena nilai korelasi antarvariabel masing-masing kurang dari 0,9 (Tabel 2). Oleh karena itu, tidak ditemukan multikolinearitas antar variabel independen. Hal ini sesuai dengan Ghozali (2013:105) yang menyatakan apabila nilai korelasi antarvariabel indepenen lebih dari 0,9, terdapat indikasi adanya multikolinearitas.

Tabel 2. Hasil Analisis Korelasi

\begin{tabular}{llll}
\hline & BelBrg & BelMod & BelPeg \\
\hline BelBrg & 1,000 & 0,612 & 0,081 \\
BelMod & 0,612 & 1,000 & 0,148 \\
BelPeg & 0,081 & 0,148 & 1,000 \\
\hline \multicolumn{3}{r}{ Sumber: } \\
\hline
\end{tabular}

Secara umum perkembangan realisasi PNBP yang dihasilkan dari pelaksanaan tugas fungsi (PNBP fungsional) dalam periode 2012-2017 menunjukkan kenaikan dalam nilai absolut Rupiah. Belanja barang dan belanja modal (DIPA PNBP) dan belanja pegawai (DIPA RM) mengalami tren serupa dengan realisasi PNBP (Grafik 2). Namun demikian, porsi belanja modal dibandingkan dengan realisasi PNBP fungsional relatif kecil yaitu rata-rata 3,85\%, jauh di bawah rerata belanja barang $(24,12 \%)$.

Selanjutnya, statistik deskriptif dari variabel yang digunakan dalam model penelitian ini, disajikan pada Tabel 3 di bawah ini. Secara rata-rata $\mathrm{K} / \mathrm{L}$ dalam sampel penelitian ini menghasilkan PNBP dari pelaksanaan tugas dan fungsi sebesar $14,63 \%$ terhadap total asetnya. Sebagai sebuah organisasi yang tidak mengerjar keuntungan, angka tersebut dapat dikatakan cukup bagus karena dapat mencapai angka melebihi 10\%.

Tabel 3. Deskripsi Statistik

\begin{tabular}{llllll}
\hline Variabel & N & Min & Max & Mean & StdDev \\
\hline $\begin{array}{l}\text { Dependen } \\
\text { PNBPFung }\end{array}$ & 144 & 0,0005 & 1,4613 & 0,1463 & 0,3161 \\
Independ & & & & & \\
en & & & & & \\
BelBrg & 144 & 0,0000 & 0,2278 & 0,0361 & 0,0544 \\
BelMod & 144 & 0,0000 & 0,0963 & 0,0072 & 0,0137 \\
BelPeg & 144 & 0,0031 & 0,8441 & 0,1700 & 0,1765 \\
\hline
\end{tabular}




\section{6}

Grafik 2: Perkembangan PNBP dan Belanja



Sumber: DJA dan DJPb

Langkah awal untuk menguji hipotesis penelitian adalah melakukan uji panel unit root terhadap data penelitian yang terdiri dari PNBPFung, BelBrg, BelMod, dan BelPeg. Pengujian yang dilakukan untuk mengetaui tingkat stationarity data tersebut menggunakan pendekatan LLC (Levin-Lin-Chia) dan IPS (Im-Pesaran-Shin) sebagaimana disajikan pada Tabel 4 berikut ini. Null hypothesis dalam pengujian unit root adalah data mengandung unit root atau tidak bersifat stasioner. Pengujian LLC dan IPS ini merupakan unit root test yang dinilai dapat memberikan hasil yang lebih baik untuk data panel dibandingkan data time series untuk setiap individu yang diobservasi (Levin et al., 2002).

Berdasarkan informasi dalam Tabel 4, diketahui bahwa hanya data PEG yang lolos uji root pada level. Oleh karena itu diperlukan pengujian unit root berikutnya dengan mengambil first difference untuk semua variabel penelitian. Hal ini dilakukan untuk memastikan bahwa seluruh data penelitian bersifat stasioner pada order pertama. Berdasarkan hasil pengujian unit root firstdifference, seluruh data penelitian bersifat stasioner. Dengan demikian, langkah berikutnya yang dilakukan adalah menguji ada tidaknya hubungan jangka panjang diantara variabelvariabel penelitian dengan menggunakan panel cointegration test.

\section{Uji Kointegrasi Data Panel}

Hasil pengujian unit root pada Tabel 4 di atas menunjukkan bahwa seluruh data penelitian bersifat stasioner pada order pertama. Mempertimbangkan hasil ini, dapat disimpulkan bahwa rangkaian tersebut terintegrasi dari orde satu dan dapat dilanjutkan untuk pengujian kointegrasi. Hipotesis nol dalam pengujian ini adalah data tidak mengalami kointegrasi. Berdasarkan hasil pengujian panel cointegration dengan menggunakan metode Kao (1999), diperoleh nilai ADF sebesar 7,038 dan signifikan pada level 1\%. Dengan demikian, kita bisa meyakini terdapat long-run equilibrium pada data PNBPFung, BrgPNBP, ModPNBP, dan PEG. Hal ini membuktikan tax-spend hypothesis dan spend-tax-hypothesis,

Tabel 4. Hasil Panel Unit Root Test

\begin{tabular}{|c|c|c|c|c|}
\hline Variable & PNBPFUNG & BRGPNBP & MODPNBP & PEG \\
\hline Levels & Statistics (p-values) & Statistics ( $p$-values) & Statistics (p-values) & Statistics (p-values) \\
\hline LLC & $-6.87952(0.0000)^{* * *}$ & $-5.47283(0.0000)^{* * *}$ & $-3.86022(0.0001)^{* * *}$ & $-11.7804(0.0000)^{* * *}$ \\
\hline IPS & $-0.63553(0.2625)$ & $\begin{array}{l}-0.22741 \\
(0.4101)\end{array}$ & $\begin{array}{l}0.91642 \\
(0.8203)\end{array}$ & $-2.32219(0.0101)^{* *}$ \\
\hline $\begin{array}{l}\text { First- } \\
\text { Differ. }\end{array}$ & & & & \\
\hline LLC & $-24.8583(0.0000)^{* * *}$ & $-10.8779(0.0000)^{* * *}$ & $-41.7739(0.0000)^{* * *}$ & $-16.5414(0.0000)^{* * *}$ \\
\hline IPS & $-8.39844(0.0000)^{* * *}$ & $-3.31867(0.0005)^{* * *}$ & $-7.98794(0.0000) * * *$ & $-5.06616(0.0000)^{* * *}$ \\
\hline
\end{tabular}

Keterangan: *** hipotesis nol ditolak pada level $1 \%$.

** hipotesis nol ditolak pada level 5\% 


\begin{tabular}{|c|c|c|c|c|c|}
\hline \multicolumn{6}{|c|}{ Tabel 5. Hasil Pengujian Kausalitas Granger } \\
\hline \multirow{3}{*}{ Dep.Var } & \multicolumn{5}{|c|}{ Sumber Penyebab (Independent) } \\
\hline & \multicolumn{2}{|c|}{ Short Run } & \multirow{2}{*}{$\begin{array}{c}\text { Long Run } \\
\text { ECT }_{\text {it-1 }}\end{array}$} & \multicolumn{2}{|c|}{ Joint (Short and Long Run) } \\
\hline & $\triangle$ PNBP FUNG & $\triangle B R G$ PNBP & & $\triangle \mathrm{PNBPFUNG/ECT}$ & $\triangle \mathrm{BRGPNBP} / \mathrm{ECT}$ \\
\hline$\triangle \mathrm{PNBPFUNG}$ & & $\begin{array}{c}27.21 \\
(0.00)^{* * *}\end{array}$ & -3.73 & - & $\begin{array}{c}0.133 \\
(0.00)^{* * *}\end{array}$ \\
\hline \multirow[t]{2}{*}{$\triangle \mathrm{BRGPNBP}$} & $\begin{array}{c}0.264 \\
(0.8762)\end{array}$ & & -0.27 & $\begin{array}{c}-0.032156 \\
(0.542)\end{array}$ & - \\
\hline & $\triangle$ PNBP FUNG & $\triangle M O D$ PNBP & $\mathrm{ECT}_{\mathrm{it}-1}$ & $\triangle \mathrm{PNBPFUNG/ECT}$ & $\triangle \mathrm{MODPNBP} / \mathrm{ECT}$ \\
\hline$\triangle$ PNBPFUNG & & $0.512933(0.4739)$ & -129 & - & $\begin{array}{c}0.0061 \\
(0.3694)\end{array}$ \\
\hline \multirow[t]{2}{*}{$\triangle \mathrm{MODPNBP}$} & $19.253(0.0001)^{* * *}$ & & -0.00 & $0.615109(0.00)^{* * *}$ & \\
\hline & $\triangle \mathrm{PNBP} F U N G$ & $\triangle \mathrm{PEG}$ & & $\triangle \mathrm{PNBPFUNG/ECT}$ & $\triangle \mathrm{PEG} / \mathrm{ECT}$ \\
\hline$\triangle$ PNBPFUNG & & $3.320(0.190)$ & -1.89 & & $\begin{array}{c}0.0395 \\
(0.0051)^{* * *}\end{array}$ \\
\hline$\triangle \mathrm{PEG}$ & $0.207(0.9015)$ & & -0.53 & $\begin{array}{c}0.021 \\
(0.238)\end{array}$ & \\
\hline
\end{tabular}

Keterangan: *** hipotesis nol ditolak pada level 1\%, ** hipotesis nol ditolak pada level 5\%

Sumber: hasil olahan

dimana pendapatan PNBP dan belanja pada K/L ternyata memiliki kointegrasi jangka panjang.

Pengujian Hipotesis

\section{a. Uji Kausalitas Granger}

Pengujian panel causality menggunakan model persamaan (1) sampai dengan (6) sebagaimana diuraikan pada bagian metodologi penelitian. Keenam persamaan tersebut dijalankan dengan metode VECM. Hal ini karena data yang diuji adalah data yang stasioner pada order pertama sehingga metode VAR biasa tidak dapat digunakan. Penggunaan Metode VECM ini dijalankan dengan melakukan estimas VAR dan memilih type vector error correction pada aplikasi e-views 9. Variabel penelitian diuji secara bergantian sebagai variabel dependen dan independen untuk melihat hubungan kausalitas secara individu antara pendapatan PNBP (PNBPFung) dan belanja pemerintah (BelBrg, BelMod, BelPeg). VECM akan menunjukkan ada tidaknya hubungan kausalitas jangka panjang. Sementara itu untuk menguji eksistensi short run causality, digunakan Wald Test. Hipotesis nol adalah tidak adanya hubungan.

Berdasarkan hasil pengujian VECM dan Wald Test (ditunjukkan dengan tanda bintang pada Tabel 5), diperoleh hasil pengujian kausalitas Granger pada Tabel 5 di bawah ini. Hubungan kausalitas yang signifikan ditemukan antara variabel $\triangle B R G P N B P$ dengan $\triangle P N B P F U N G$ ketika menjadikan variabel $\triangle P N B P F U N G$ sebagai variabel dependen. Hubungan tersebut dijumpai baik untuk short, long-run, maupun joint.
Sebaliknya, ketika variabel $\triangle B R G P N B P$ dijadikan sebagai variabel dependen dan variabel $\triangle P N B P F U N G$ sebagai variabel independen, ternyata variabel $\triangle P N B P F U N G$ tidak memberikan efek terhadap $\triangle B R G P N B P$. Hal ini berarti hubungan kausalitas antara pendapatan PNBP fungsional dan belanja barang hanya bersifat satu arah yaitu, BelBrg mempengaruhi PNBPFung. Hal ini sejalan dengan spend-tax hypothesis dimana belanja pemerintah dapat mendorong penerimaan negara, namun tidak sebaliknya.

Hubungan antara variabel $\triangle P N B P F U N G$ dan $\triangle M O D P N B P$ juga bersifat satu arah. Hal terlihat dari hasil pengujian yang signfikan ketika menjadikan $\triangle M O D P N B P$ sebagai variabel dependen dan $\triangle P N B P F U N G$ sebagai variabel penjelas. Sebaliknya, ketika variabel $\triangle P N B P F U N G$ dijadikan sebagai variabel dependen dan $\triangle M O D P N B P$ dijadikan sebagai variabel independen, hasil pengujian justru gagal menolak Ho yang berupa ketiadaan hubungan antara kedua variabel tersebut. Dengan demikian, dapat dikatakan hasil ini memperkuat tax-spend hypothesis dimana pendapatan negara justru dapat mendorong tingginya belanja negara. Hubungan kausalitas satu arah dari $\triangle P N B P F U N G$ ke $\triangle$ MODPNBP dijumpai baik untuk kausalitas jangka pendek, jangka panjang, maupun gabungan.

Selanjutnya, hubungan kausalitas satu arah juga dijumpai ketika $\triangle P E G$ dijadikan sebagai variabel independen untuk menjelaskan dinamika $\triangle$ PNBPFUNG pada tataran joint (short and long run). Hal ini mengindikasikan bahwa belanja pegawai memberikan makna terhadap besar 


\section{8}

kecilnya pendapatan PNBP. Hasil ini mendukung spend-tax hypothesis. Namun demikian, hubungan kausalitas tidak dijumpai pada model short run dan long run secara terpisah. Demikian juga hasil tidak signifikan dijumpai ketika menjadikan $\triangle$ PNBPFUNG sebagai variabel penjelas untuk variabel $\triangle \mathrm{PEG}$

\section{b. Regresi data panel}

Selanjutnya, untuk mengkonfirmasi hasil pengujian kausalitas Granger di atas, peneliti juga melakukan analisis regresi panel. Dalam penelitian ini, model panel dipilih setelah melalui pengujian Chow Test (untuk memilih model OLS atau fixed effect model), hausman test (untuk memilih fixed atau random effect), dan Lagrange Multiplier/ Breusch Pagan Test (untuk memilih OLS atau random effect). Prosedur pengujian pemilihan model regresi panel ini sesuai dengan yang dijelaskan oleh Gujarati (2003). Berdasarkan pengujian dimaksud, diperoleh hasil bahwa model regresi panel yang sesuai untuk digunakan dalam

\begin{tabular}{lcc}
\hline \multicolumn{1}{c}{ Jenis Pengujian } & Statistic & Prob \\
\hline $\begin{array}{l}\text { Chow Test (Ho: no effect) } \\
\text { Hasuman Test (Ho: cross }\end{array}$ & $56.125^{* * *}$ & 0.000 \\
$\begin{array}{l}\text { section random) } \\
\text { Lagrange Multiplier Test }\end{array}$ & 6.608 & 0.085 \\
$\begin{array}{l}\text { (Ho: no effect) } \\
\text { Breusch Pagan }\end{array}$ & & \\
Honda & $279.383^{* *}$ & 0.000 \\
\end{tabular}

penelitian ini adalah random effect model (REM). Ikhtisar pengujian pemilihan model panel disajikan pada Tabel 6 berikut ini

Tabel 6. Hasil Pengujian Pemilihan Model Keterangan: *** hipotesis nol ditolak pada level 1\% ** hipotesis nol ditolak pada level 5\%

Sumber: hasil olahan

Selanjutnya, hasil analisis regresi REM selengkapnya disajikan pada Tabel 7. Hipotesis nol untuk pengujian t-statistic adalah tidak adanya pengaruh variabel independen terhadap variabel dependen. Sementara hipotesis nol untuk F-statistic adalah tidak adanya pengaruh secara simultan dari seluruh variabel independen terhadap variabel dependen. Hasil pengujian regresi dengan menggunakan persamaan (7) dapat diliaht pada Tabel 7 di bawah ini.

Tabel 7. Analisis Regresi REM Variabel dependen: PNBPFUNG

\begin{tabular}{|c|c|c|c|}
\hline $\begin{array}{l}\text { Variabel } \\
\text { Independen }\end{array}$ & Prediksi & Koefisien & Prob. \\
\hline BelBrg & + & 0,9680 & $0,0039 * * *$ \\
\hline BelMod & + & 0,9370 & 0,4246 \\
\hline BelPeg & + & 0,0578 & 0,7464 \\
\hline R-squared & 0.069806 & & \\
\hline Adj. R-sq. & 0.049846 & & \\
\hline F-Stat & 3.50208 & & $0.0172^{* *}$ \\
\hline
\end{tabular}

Keterangan: ${ }^{* * *}$ hipotesis nol ditolak pada level $1 \%$ ** hipotesis nol ditolak pada level $5 \%$.

Sumber: hasil olahan

Berdasarkan Tabel 7 di atas, terlihat bahwa adjusted R-square sangat kecil, yaitu hanya sebesar 4,98\%. Hal ini berarti masih terdapat banyak variabel yang perlu dimasukkan dalam model penelitian ini agar hasil regresi menjadi lebih robust. Rendahnya nilai adjusted R-squared terjadi karena penelitian ini hanya memfokuskan variabel independen dari supply side (internal $\mathrm{K} / \mathrm{L}$ ), khususnya dari sisi penganggaran dan tidak memasukkan variabel dari demand side (eksternal K/ L). Ditinjau dari perspektif demand side, terdapat komponen PNBP yang sangat rentan terhadap parameter ekonomi makro seperti nilai tukar dan harga komoditas, yaitu PNBP dari sumber daya alam, khususnya pertambangan umum yang dikelola oleh Kementerian ESDM. Disamping itu, karakteristik pemungutan PNBP dari sumber daya alam yang bersifat self assessment, kinerja PNBP dipengaruhi pula oleh tingkat kepatuhan wajib bayar. Oleh karena itu, variabel tersebut di atas layak dipertimbangkan sebagai variabel penelitian dari sisi demand side di masa mendatang.

Ditinjau dari sisi internal K/L (supply side), beberapa variabel seperti sistem pengendalian internal, kepatuhan $\mathrm{K} / \mathrm{L}$ terhadap peraturan perundangan, dan motivasi pegawai dapat pula dipertimbangkan sebagai variabel bebas dalam model penelitian di masa mendatang. Asriyanti (2018) mengungkapkan dalam riset studi kasus pada Ditlantas Polda Sulsel bahwa pengendalian internal dan kepatuhan instansi pemerintah terhadap peraturan perundangan menjadi syarat dalam terwujudnya efektivitas pengelolaan PNBP fungsional. Dalam studi kasus pengelolaan PNBP pada Universitas Syah Kuala Aceh (Unsyiah), Jaya (2011) menjelaskan bahwa motivasi kerja dan pelaksanaan fungsi manajemen keuangan secara total berpengaruh terhadap pelaksanaan akuntabilitas keuangan pada Unsyiah, Aceh.

Hasil penelitian di atas menunjukkan hanya variabel belanja barang yang berpengaruh positif signifikan terhadap kinerja PNBP, sementara belanja modal dan belanja pegawai gagal menjadi variabel penjelas yang signifikan.

\section{Pembahasan}

\section{a. Belanja Barang}

Hipotesis pertama dalam penelitian ini adalah adanya hubungan kausalitas antara belanja barang yang bersumber dari DIPA PNBP (BelBrg) dengan kinerja PNBP fungsional K/ L (PNBPFung). Hasil pengujian Granger menunjukkan bahwa belanja barang DIPA-PNBP memberikan pengaruh positif 
terhadap realisasi PNBP yang dihasilkan dari pelaksanaan tugas dan fungsi $\mathrm{K} / \mathrm{L}$. Hal ini sejalan dengan spend and tax hypothesis yang dikemukakan oleh Peacock \& Wiseman $(1961$,$) . Hubungan$ kausalitas tersebut dijumpai pada short run, long run, dan joint causality. Hasil riset ini memberikan gambaran bahwa pendapatan negara yang bersumber dari layanan publik tersebut sangat tergantung dengan alokasi belanja barang yang dilakukan oleh K/ L. Alokasi belanja barang tersebut diambilkan dari sebagian dana PNBP yang dipungut oleh K/ L yang bersangkutan. Hubungan positif satu arah dari pengeluaran ke pendapatan negara ini sejalan dengan riset Ghazo \& Abu-Lila (2018). Dalam riset yang dilakukan di Jordan dalam periode 1976-2017 tersebut, Ghazo \& Abu-Lila (2018) menemukan adanya hubungan kausalitas satu arah dari pengeluaran negara terhadap pendapatan pajak langsung dan tidak langsung.

Namun demikian, hasil riset ini tidak sejalan dengan hasil riset yang mengamati hubungan kausalitas dinamis antara pengeluaran dan pendapatan negara di Indonesia selama kurun waktu 1963-2017 (Sani et al 2018). Studi time-series tersebut menemukan adanya hubungan negatif, dimana pengeluaran negara yang naik sepanjang waktu pengamatan, justru diiringi dengan penurunan pendapatan. Hal ini yang menimbulkan adanya defisit anggaran setiap tahunnya. Perbedaan hasil riset Sani et al (2018) dengan penelitian ini antara lain disebabkan oleh objek pendapatan yang diteliti. Penelitian Sani et al (2018) menggunakan data seluruh pendapatan negara sementara penelitian kami hanya fokus pada pendapatan PNBP. Adanya perbedaan karakteristik antara pendapatan pajak dan PNBP di Indonesia merupakan salah satu penyebab hasil riset yang berbeda. Pendapatan pajak merupakan pendapatan yang bersifat memaksa sementara PNBP banyak bertumpu pada pelayanan masyarakat atas dasar permintaan publik.

Di sisi lain, hubungan kausalitas dari pendapatan PNBP hasil pelaksanaan tugas dan fungsi ke arah realisasi belanja barang PNBP ternyata tidak signifikan secara statistik. Kondisi ini berbeda dengan semangat UU PNBP yang memberikan hak penggunaan dana PNBP bagi K/ L selaku instansi pengelola PNBP. K/ L diduga tidak banyak menggunakan sebagian dana PNBP untuk alokasi belanja barang.

Hasil pengujian kausalitas Granger didukung hasil regresi panel. Nilai koefisien estimasi untuk variabel belanja barang pada Tabel 7 di atas adalah sebesar 0,9680 dengan $p$-value $=0,0039$. Nilai koefisien untuk variabel BelBrg sebesar 0,9680 mengindikasikan bahwa setiap belanja barang per total aset sebesar Rp1 yang direalisasikan oleh K/ L akan memberikan dampak terhadap kenaikan realisasi PNBP pelaksanaan tugas dan fungsi per total aset sebesar $\mathrm{Rp} 0,9680$.

Hasil penelitian ini tidak sejalan dengan hasil penelitian Deswantoro et al. (2017) dan Astiti \& Mimba (2016). Perbedaan hasil penelitian ini dengan kedua penelitian terakhir antara lain disebabkan oleh karakteristik belanja barang yang dikelola. Belanja barang di pemerintah daerah tidak dialokasikan berdasarkan prinsip terikat dengan pendapatan (earmarked revenue). Adapun belanja barang dalam penelitian ini menggunakan realisasi belanja barang yang terikat (earmarked budget).

Belanja barang yang memberikan kontribusi positif terhadap capaian realisasi PNBP fungsional mengindikasikan bahwa pengeluaran pemerintah berupa belanja barang terbukti efektif dalam mendukung kinerja pelayanan yang memungut PNBP dari masyarakat. Belanja barang yang sejalan dengan kinerja pelayanan terutama dapat berasal dari pembelian bahan baku dan biaya pemeliharaan yang berkaitan langsung dengan kegiatan penyediaan barang dan jasa kepada masyarakat yang berbasis pungutan PNBP. Hasil riset ini sejalan dengan filosofi peraturan perundangan di bidang PNBP. Di dalam UU No 9 Tahun 2018 tentang PNBP dan PP Nomor 58 Tahun 2020 tentang Pengelolaan PNBP, dijelaskan bahwa setiap K/L dapat menggunakan sebagian dana untuk menyelenggarakan dan meningkatkan kualitas layanan PNBP serta upaya optimalisasi PNBP. Penggunaan dana belanja barang DIPA-PNBP yang efektif diduga menjadi salah satu determinan penting dalam pencapaian realisasi PNBP.

Hasil riset tersebut juga memberikan implikasi bahwa dengan rata-rata realisasi belanja barang per total aset sebesar 3,61\% ternyata telah memberikan korelasi yang signifikan terhadap peningkatan capaian PNBP fungsional. Oleh karena itu, K/ L dapat lebih memprioritaskan alokasi belanja barang untuk meningkatkan kualitas layanan sekaligus mendukung upaya optimalisasi PNBP di kemudian hari.

\section{b. Belanja Modal}

Hipotesis kedua dalam penelitian ini berkaitan dengan hubungan kausalitas antara belanja modal dan kinerja PNBP yang bersifat earmarked budget. Hasil pengujian menunjukkan adanya unidirectional causality antara belanja modal dan PNBP. Belanja modal DIPA-PNBP banyak didorong oleh capaian realisasi PNBP sementara belanja modal dari dokumen penganggaran yang sama justru tidak bisa memberikan efek positif terhadap pendapatan negara.

Fenomena ini cukup menarik ketika dihubungkan dengan dampak belanja barang terhadap realisasi PNBP layanan publik. K/ L lebih banyak memanfaatkan dana PNBP untuk pembelian 


\section{0}

aset tetap. Belanja modal tersebut di sisi lain justru kurang efektif dalam mendorong capaian PNBP. Hal ini ditunjukkan juga dengan nilai estimasi pada Tabel 7. Diketahui bahwa koefisien untuk belanja modal per total aset (BelMod) adalah sebesar 0,9370 dengan p-value sebesar 0,4246. Artinya, riset ini tidak bisa menerima hipotesis kedua (yang menyatakan terdapat pengaruh positif belanja modal terhadap PNBP), sebagai hipotesis alternatif. Oleh karena itu, sesuai hipotesis nol, tidak terdapat pengaruh positif belanja modal terhadap realisasi PNBP. Hasil penelitian ini tidak berhasil mengkonfirmasi riset terdahulu yang sebagian besar menemukan pengaruh positif belanja modal terhadap kinerja keuangan pemerintah (Iswari 2018, Deswantoro, et al., 2017, Darwis, 2015, Puspitasari et al., 2015, dan Darwanis \& Saputra 2014).

Realisasi belanja modal yang tidak berdampak secara positif dan signifikan terhadap capaian realisasi PNBP dapat terjadi karena realisasi belanja modal per total aset pada $\mathrm{K} / \mathrm{L}$ yang diamati secara rata-rata hanya sebesar $0,72 \%$, jauh di bawah realisasi belanja barang per total aset yang rata-rata sebesar 3,61\%. Disamping itu, terdapat beberapa kemungkinan lain yang layak dipertimbangkan. Pertama, realisasi belanja modal yang berupa pengadaan aset tetap seperti tanah, bangunan, peralatan dan mesin, tidak dapat dirasakan manfaatnya dalam jangka pendek. Seperti diketahui, proses pengadaan barang dan jasa membutuhkan tahapan dan prosedur yang cukup panjang. Faktor yang paling memengaruhi keterlambatan realisasi belanja modal yaitu penyusunan rencana kegiatan anggaran belanja modal yang kurang baik (Sani, 2018). Ditambah lagi apabila proses pengadaan barang dan jasa baru dimulai pada pertengahan tahun, aset tetap baru tersedia untuk digunakan oleh instansi pemerintah menjelang akhir tahun. Oleh karena itu, pengadaan aset tetap yang berasal dari belanja modal dirasa kurang memberikan dampak signifikan terhadap layanan berbasis PNBP pada tahun berjalan.

Kedua, belanja modal digunakan untuk pengadaan aset tetap yang tidak berkaitan langsung dengan kegiatan pelayanan PNBP. Satker penghasil PNBP mempunyai keleluasaan untuk membeli aset tetap yang dibutuhkan meski aset tetap tersebut tidak berkaitan langsung dengan kegiatan pelayanan PNBP. Sebagai contoh, pengadaan mobil dinas pada instansi pemerintah kerap kali menggunakan dana PNBP. Hal ini sejalan dengan budget maximizing theory, dimana entitas pemerintah mempunyai diskresi dalam pengelolaan anggaran yang dipandang dapat memberikan manfaat lebih bagi instansi yang bersangkutan.
Ketiga, adanya dualisme sistem pengelolaan PNBP yaitu, pengelolaan PNBP secara terpusat dan tersebar. Pengelolaan PNBP secara terpusat memungkinkan Sekretariat Jenderal atau Sekretariat Utama pada K/L bertindak selaku koordinator yang mengatur alokasi pagu penggunaan PNBP. Dana PNBP yang dihasilkan oleh satker A dapat digunakan untuk mendukung tugas dan fungsi satker B yang sejatinya bukan merupakan instansi pemungut PNBP. Instansi yang menerapkan sistem terpusat ini antara lain adalah Kepolisian Republik Indonesia. Sebaliknya, sistem pengelolaan PNBP tersebar, dirasa lebih rigid. Dana PNBP hanya dapat digunakan oleh satker yang melakukan pungutan PNBP. Instansi pemerintah yang mengadopsi sistem tersebut antara lain adalah Kementerian Negara Agraria/ Badan Pertanahaan Nasional.

Realisasi belanja modal dari DIPA-PNBP pada Kepolisian RI selama 2016-2017 menduduki peringkat pertama diantara objek penelitian yang lain (mencapai Rp2,3 triliun). Sementara realisasi belanja modal per total aset tertinggi sebesar 9,63\% dicetak oleh Kementerian Negara Agraria/Badan Pertanahan Nasional. Dua instansi terbesar dalam penyerapan belanja modal dengan sistem pengelolaan PNBP yang berbeda, diduga menjadi salah satu penyebab ketiadaan pengaruh positif belanja modal terhadap capaian PNBP. Fenomena ini sejalan dengan teori ilusi fiskal, dimana instansi pemerintah yang mempunyai target pendapatan besar, perlu didukung anggaran belanja yang besar pula. Meskipun demikian, diskresi anggaran sebagaimana dijelaskan dalam budget maximizing theory, memberikan keleluasaan pengelolaan dana PNBP apakah menggunakan sistem PNBP terpusat atau mengadopsi pendekatan PNBP tersebar.

\section{c. Belanja Pegawai}

Hipotesis ketiga dalam penelitian ini ingin mengkonfirmasi apakah terdapat hubungan kausalitas antara belanja pegawai terhadap kinerja PNBP. Hasil pengujian Granger menunjukkan adanya hubungan positif dari belanja pegawai terhadap realisasi PNBP dari tugas utama $\mathrm{K} / \mathrm{L}$. Hubungan kausalitas positif tersebut hanya dijumpai satu arah dari belanja pegawai ke arah realisasi PNBP. Namun demikian hubungan kausalitas tersebut tidak dijumpai pada jangka pendek dan panjang secara terpisah, namun pada joint causality.

Berdasarkan Tabel 7, angka koefisien untuk variabel BelPeg adalah 0,0578 dengan p-value sebesar 0,7464. Hasil estimasi ini menunjukkan bahwa kita tidak bisa menolak null hypothesis berupa ketiadaan pengaruh belanja pegawai terhadap realisasi PNBP. Dengan kata lain, riset ini tidak berhasil mengkonfirmasi pengaruh positif 
insentif yang diperoleh Aparatur Sipil Negara (ASN) terhadap kinerja PNBP. Hasil riset ini sejalan dengan Astiti \& Mimba ( 2016). Kondisi ini bisa jadi karena capaian realisasi PNBP tidak kewajiban individu bagi tiap ASN yang ditugaskan dalam pengelolaan PNBP. Kewajiban individu birokrat tersebut dapat dituangkan dalam kontrak kinerja. Jika capaian realisasi PNBP tidak menjadi indikator kinerja utama (IKU) pegawai, maka pegawai kurang termotivasi untuk melakukan tugas optimalisasi PNBP secara totalitas.

Sesuai dengan teori keagenan, seringkali terjadi perbedaan kepentingan antara rakyat selaku principal dan birokrat selaku agent. Masyarakat mempunyai ekspektasi bahwa dengan adanya perbaikan remunerasi yang diperoleh ASN, diharapkan kinerja pelayanan para abdi negara menjadi meningkat. Sementara itu, sebagian dari ASN barangkali sudah merasakan comfort zone dengan memperoleh penghasilan yang memadai tanpa perlu disibukkan dengan upaya peningkatan kinerja. Disadari sepenuhnya bahwa capaian realisasi PNBP bukan merupakan satu-satunya tolok ukur kinerja PNS. PNS dari satker BLU biasanya memperoleh penghasilan yang lebih tinggi dibandingkan koleganya di satker non BLU. Hal ini karena dalam sistem remunerasi BLU, para pegawai BLU dapat memperoleh insentif tambahan di luar gaji dan tunjangan melekat. Ketiadaan dampak belanja pegawai terhadap capaian realisasi PNBP bisa jadi disebabkan oleh sistem remunerasi dalam satker BLU yang belum sepenuhnya menjalankan prinsip-prinsip yang diatur di dalam Peraturan Menteri Keuangan (PMK) Nomor 176/ PMK.05/ 2017 tentang pedoman Remunerasi pada Badan Layanan Umum. Beberapa prinsip tersebut adalah pay for people, pay for performance, pay for people dan kinerja operasional. Remunerasi yang tidak didesain berbasis prinsip pay for performance, dimana kinerja dijadikan sebagai basis pemberian remunerasi, diduga menjadi penyebab ketiadaan pengaruh belanja pegawai terhadap kinerja PNBP.

Disamping itu, Putra dan Afriansyah (2019) menjelaskan bahwa remunerasi bersifat single salary yang mengakomodasi semua imbalan yang diterima oleh pegawai BLU berupa gaji, tunjangan tetap, honorarium, insentif, dan bonus. Dalam penelitiannya pada BLU pendidikan, Putra dan Afriansyah (2019) menemukan bahwa penerapan single salary pada BLU pendidikan tersebut masing tergolong rendah. Hal ini terlihat dari masih banyaknya honor-honor selain remunerasi yang diterima oleh pegawai BLU seperti honor pengantar SPM, pengambil SP2D, tim teknis penyusunan anggaran, tunjangan direktur, tunjangan wakil direktur, honor penyunting jurnal, honor perangkat pembantu pengelola administrasi negara dan lain sebagainya. Dengan demikian, penulis berpendapat bahwa penerapan single salary yang belum optimal tersebut dapat pula menjadi penyebab dari nihilnya pengaruh belanja pegawai terhadap capaian realisasi PNBP K/ L secara keseluruhan.

\section{KESIMPULAN}

Penelitian ini bertujuan untuk mengamati hubungan kausalitas antara realisasi PNBP yang dihasilkan dari pelaksanaan tugas dan fungsi dengan penyerapan anggaran belanja tingkat $\mathrm{K} / \mathrm{L}$ sebelum implementasi UU Nomor 9 Tahun 2018. Hasil penelitian mengungkapkan adanya hubungan kausalitas secara Granger yang bersifat unidirectional dari belanja barang DIPA-PNBP terhadap capaian PNBP baik dalam jangka pendek maupun panjang. Hasil ini dikonfirmasi oleh pengujian regresi panel dengan random effect model. Studi ini memberikan konfirmasi atas spend and tax hypothesis yang menjelaskan bahwa pengeluaran yang dilakukan oleh negara pada akhirnya akan mendorong penerimaan negara.

Hasil riset ini mengungkapkan adanya hubungan kausalitas satu arah dari capaian PNBP terhadap belanja modal DIPA-PNBP. Hubungan ini dijumpai pada joint causality, namun tidak ditemukan pada short run dan long run causality secara terpisah. Hasil ini memberikan dukungan terhadap tax and spend hypothesis yang mengemukakan pendapat bahwa belanja negara didukung oleh sumber penerimaan negara. Oleh karena itu, analisis random effect model yang tidak menemukan dampak positif belanja modal terhadap realisasi PNBP, turut mendukung temuan unidirectional causality dari PNBP terhadap belanja modal tersebut.

Studi ini tidak berhasil menemukan dampak signifikan belanja pegawai terhadap realisasi PNBP melalui random effect model. Namun demikian, berdasarkan pengujian Granger causality, ditemukan joint causality satu arah dari belanja pegawai terhadap kinerja PNBP dari layanan publik tersebut.

Hasil riset ini memberikan insight agar pengelolaan belanja $\mathrm{K} / \mathrm{L}$ lebih selektif digunakan untuk mendukung tugas dan fungsi $\mathrm{K} / \mathrm{L}$ khususnya layanan yang berbasis pungutan PNBP. Alokasi belanja yang mendukung upaya peningkatan kualitas layanan dan optimalisasi PNBP, seperti belanja barang, hendaknya memperoleh porsi yang lebih besar dibandingkan dengan jenis belanja yang lain. Penelitian ini memberikan implikasi kebijakan berupa perlunya evaluasi terhadap alokasi belanja yang bersumber dari dana PNBP yang diamanatkan oleh peraturan perundangan bidang PNBP sebelumnya, yaitu UU Nomor 20 Tahun 1997. Hasil studi menunjukkan bahwa belanja barang terbukti efektif dalam mendorong capaian PNBP. Namun demikian, K/L diduga lebih cenderung untuk 


\section{2}

memanfaatkan dana PNBP untuk menambah pagu belanja modal. Adanya mismatch anggaran ini diharapkan dapat diminimalkan untuk mendukung upaya pemerintah dalam melakukan optimalisasi PNBP.

Hasil riset ini juga mengkonfirmasi perlunya instansi pengelola PNBP menjadikan belanja barang PNBP sebagai prioritas belanja dalam penyusunan Rencana Kerja dan Anggaran K/ L (RKA-KL). Proses pengadaan barang dan jasa pada instansi pemerintah dapat lebih dipercepat untuk meningkatkan efektivitas pemanfaatan aset tetap dalam pelayanan PNBP. Kebijakan penggunaan dana PNBP yang diamanatkan oleh UU Nomor 9 Tahun 2018 dan peraturan pelaksanaannya diharapkan dapat mendorong pemanfaatan belanja modal yang lebih efektif.

Insentif PNS berupa remunerasi dapat dipertimbangkan untuk dikaitkan dengan kinerja layanan PNBP. Hal ini karena, selama ini penggunaan dana PNBP tidak ditujukan untuk menambah belanja pegawai bagi instansi pengelola PNBP. Dengan demikian, insentif belanja pegawai yang dikaitkan dengan kinerja PNBP dapat dipertimbangkan untuk diberikan. Hal ini sebagaimana remunerasi pegawai Direktorat Jenderal Pajak yang dikorelasikan dengan capaian realisasi pendapatan perpajakan. Remunerasi untuk pegawai BLU perlu dievaluasi apakah telah sepenuhnya menerapkan prinsip yang diatur dalam peraturan remunerasi BLU

Dari sisi akademik, penelitian ini menambah bukti empiris yang mendukung adanya hubungan positif antara pengeluaran dan pendapatan negara. Penelitian ini diharapkan dapat mendorong lahirnya penelitian di bidang PNBP baik yang bersifat mikro maupun makro.

Sebagaimana dimaklumi bahwa tidak semua satuan kerja pada K/L merupakan instansi penyelenggara layanan berbasis PNBP. Oleh karena itu, pengamatan yang lebih baik akan diperoleh apabila penelitian selanjutnya menggunakan data realisasi PNBP dan kinerja penyerapan anggaran belanja pada sejumlah $\mathrm{K} / \mathrm{L}$ lainnya yang belum diamati dalam riset ini. Ketiadaan data pada beberapa K/L tertentu dapat diatasi dengan menggunakan analisis unbalanced panel. Riset selanjutnya juga dapat dilakukan pada tingkat satuan kerja pengelola PNBP untuk mendapatkan gambaran lebih jelas pada tingkat mikro.

Penelitian ini tidak berhasil mengkonfirmasi dampak belanja modal yang berasal dari DIPA PNBP, antara lain dengan alasan manfaat belanja modal yang baru dirasakan di tahun berikutnya. Oleh karena itu, dalam penelitian selanjutnya, dapat dipertimbangkan untuk menggunakan variabel realisasi belanja modal pada tahun sebelumnya sebagai salah satu variabel independen.

Disadari sepenuhnya bahwa terdapat kemungkinan munculnya bias measurement error khususnya mengenai pengukuran realisasi PNBP fungsional. Hal ini dapat terjadi karena beberapa laporan keuangan $\mathrm{K} / \mathrm{L}$ tidak secara jelas mengungkapkan nilai realisasi PNBP yang berkaitan langsung dengan tugas dan fungsi. Artinya, laporan keuangan K/L tidak mengungkapkan jenis PNBP mana saja yang bersifat earmarking budget. Peneliti melakukan perhitungan sendiri berdasarkan professional judgement. Oleh karena itu, penelitian selanjutnya diharapkan dapat menggunakan data realisasi PNBP pelaksanaan tugas dan fungsi yang lebih reliable dengan memanfaatkan database realisasi PNBP pada Sistem Informasi PNBP Online (SIMPONI).

Disamping keterbatasan tersebut di atas, penelitian selanjutnya dapat juga menggunakan variabel lain berupa sistem pengendalian internal, kepatuhan K/L dalam pengelolaan PNBP, faktor kepemimpinan, dukungan teknologi informasi dan kompetensi pegawai. Variabel eksternal seperti kepatuhan wajib bayar dalam menaati ketentuan pembayaran PNBP layak dipertimbangkan pula sebagai variabel penelitian di masa mendatang. Pengamatan data untuk waktu yang lebih panjang, meliputi periode sebelum dan sesudah penerapan UU Nomor 9 Tahun 2018, diduga akan memberikan hasil yang lebih baik. Untuk mendalami persoalan alokasi belanja dan realisasi PNBP penelitian berikutnya dapat pula menggunakan pendekatan mixed method.

\section{PENGHARGAAN}

Penulis menyampaikan ucapan terima kasih dan apresiasi yang setinggi-tingginya kepada Politeknik Keuangan Negara STAN yang telah mendanai riset ini. Kami berterima kasih pula kepada para reviewer, baik reviewer internal PKN STAN maupun reviewer Itrev yang telah memberikan masukan yang konstruktif bagi peningkatan kualitas hasil penelitian ini. Kami bertanggung jawab sepenuhnya terhadap hasil riset ini termasuk error yang mungkin terjadi.

\section{DAFTAR PUSTAKA}

Abdulrasheed, B. (2017). Causality between government expenditure and government revenue in Nigeria. Asian Journal of Economics and Empirical Research, 4(2):91-98.

Agusti, A. F., Rossieta, H., \& Siswantoro, D. (2014). Faktor Determinan Akuntabilitas dan 
Transparansi Kementerian/ Lembaga. Simposium Nasional Akuntansi.

Al-Khulaifi, A. S. (2012). The Relationship between Government Revenue and Expenditure in Qatar: A Cointegration and Causality Investigation. International Journal of Economics and Finance, 4(9), 142-148.

Aminu, A., \& Raifu, I. A. (2019). Dynamic Nexus between Government Revenues and Expenditures in Nigeria: Evidence from Asymmetric Causality and Cointegration Methods. MPRA Paper No. 97880.

Asriyanti, M. (2018). Sistem Pengendalian Internal atas Penerimaan Negara Bukan Pajak (PNBP) PP no. 60 Tahun 2016: Studi Kasus pada Direktorat Lalu Lintas Makassar. Doctoral dissertation, Universitas Islam Negeri Alauddin Makassar.

Astiti, D. N.Y., \& Mimba, N. P. S. H. (2016). Pengaruh Belanja Rutin dan Belanja Modal Pada Kinerja Keuangan Pemerintah Daerah. Jurnal Universitas Udayana. Bali, 14(3).

Bierhanzl, E. J., \& Downing, P. B. (2004). User charges and special districts. Management policies in local government finance, 315-351.

Borge, L. E., \& Rattsø, J. (2003). The Relationships Between Costs and User charges: The Case of a Norwegian Utility Service. CESifo Working Paper No. 1033.

Buchanan, J. M. (1963). The economics of earmarked taxes.Journal of political economy, 71(5), 457-469.

Cui, W. (2013). User Fee Study in Central Texas: Describing How User Fee Structures Are Treated In the FY 2012-13 Budget Documents of Cities in Central Texas. Theses. Department of Political Science Texas State University-San Marcos.

Darwanis, D., \& Saputra, R. (2014). Pengaruh Belanja Modal terhadap Pendapatan Asli Daerah dan Dampaknya Pada Kinerja Keuangan Pemerintah Daerah (Studi Empiris Pada Pemerintah Daerah Kabupaten/ Kota Di Provinsi Aceh). Jurnal Dinamika Akuntansi dan Bisnis, 1(2), 183-199.

Darwis, E. T. R. (2015). Pengaruh Belanja Modal Dan Belanja Pegawai Terhadap Tingkat Kemandirian Keuangan Daerah Pada Kabupaten/ Kota Provinsi Sumatera Barat (Studi Empiris Pada Kabupaten dan Kota Provinsi Sumatera Barat). Jurnal Akuntansi, 3(1).

Deswantoro, D. B., Ismail, A., \& Hendarmin, H. (2017). Pengaruh belanja daerah berdasarkan klasifikasi ekonomi terhadap pertumbuhan ekonomi dan kesejahteraan masyarakat di kabupaten/kota Provinsi Kalimantan Barat tahun 2010-2015. Jurnal Ekonomi Bisnis Dan Kewirausahaan, 6(3), 187.
Downing, P. B. (1984). User charges and Service Fees." In Crisis and Constraint in Municipal Finance: Local Fiscal Prospects in a Period of Uncertainty, 160-199.

Engle, R. F., \& Granger, C. W. (1987). Co-integration and error correction: representation, estimation, and testing. Econometrica: journal of the Econometric Society, 55(2), 251-276.

Friedman, M. (1978). The limitations of tax limitation. Policy Review. 7-14

Ghozali, I. (2013). Aplikasi Analisis Multivariate dengan Program IBM SPSS 21 Update PLS Regresi. Semarang: Badan Penerbit Universitas Diponegoro

Ghazo, A., \& Abu-Lila, Z. (2018). Causalities between Components of Public Revenues, and Public Expenditures in Jordan Causalities between Components of Public Revenues, and Public Expenditures in Jordan. International Journal of Academic Research in Economics and Management Sciences, 7(2): 59-71.

Gounder, N., Narayan, P. K., \& Prasad, A. (2007). An empirical investigation of the relationship between government revenue and expenditure: The case of the Fiji Islands. International Journal of Social Economics, 34(3), 147-158.

Gujarati, D. ( 2003). Basic Econometric. 4th edition. Singapore:McGraw-Hill Book Co.

Heryana, T. (2014). Analisis Flypaper Effect Belanja Pemerintah Daerah di Indonesia Berbasis Vector Autoregressive (VAR). Jurnal Wacana Kinerja, 17(2), 1-19.

Im, K. S., Pesaran, M. H., \& Shin, Y. (2003). Testing for unit roots in heterogeneous panels. Journal of econometrics, 115(1), 53-74.

Iswari, N. N. (2018). Pengaruh Perubahan Belanja Modal, Perubahan Pendapatan Asli Daerah, Dan Realisasi Dana Bagi Hasil Pajak Terhadap Sisa Lebih Pembiayaan Anggaran (Silpa) (Studi Empiris di Pemerintah Daerah Kabupaten/Kota Se-Jawa Tahun 2016). Publikasi Ilmiah. Doctoral dissertation, Universitas Muhammadiyah Surakarta.

Jaya, A. S. F. (2011). Pengaruh Motivasi Kerja Terhadap Pelaksanaan Fungsi Manajemen Keuangan Dalam Pengelolaan Pendapatan Negara Bukan Pajak (Pnbp) Dan Dampaknya Terhadap Pelaksanaan Akuntabilitas Keuangan Pada Universitas Syiah Kuala. Jurnal Telaah dan Riset Akuntansi, 4(1), 1-20.

Jensen, M. C., \& Meckling, W.H. (1976). Theory of the firm: Managerial behavior, agency costs and ownership structure. Journal of financial economics, 3(4), 305-360.

Jung, C., \& Bae, S. (2011). Changing revenue and expenditure structure and the reliance on user charges and fees in American counties, 1972-2002. The American Review of Public Administration, 41(1), 92-110. 


\section{4}

Kao, C. (1999). Spurious regression and residualbased tests for cointegration in panel data. Journal of econometrics, 90(1), 1-44.

Kurniasih, D. A. (2016). Pembaharuan Pengelolaan Penerimaan Negara Bukan Pajak. Jurnal Rechtsvinding, 5(2), 212-227.

Levin, A., Lin, C. F., \& Chu, C. S. J. (2002). Unit root tests in panel data: asymptotic and finitesample properties. Journal of econometrics, 108(1), 1-24.

Magazzino, C. (2014). The relationship between revenue and expenditure in the ASEAN countries. East Asia, 31(3), 203-221.

Mehrara, M., Pahlavani, M., \& Elyasi, Y. (2011). Government revenue and government expenditure nexus in Asian countries: Panel cointegration and causality. International Journal of Business and Social Science, 2(7), 199-207.

Meltzer, A. H., \& Richard, S. F. (1981). A rational theory of the size of government. Journal of political Economy, 89(5), 914-927.

Mercer, L. J., \& Morgan, W. D. (1983). The relative efficiency and revenue potential of local user charges: The California case. National Tax Journal, 36(2), 203-212.

Musgrave, R. (1966). Principles of budget determination. Public finance: Selected readings, 15-27.

Narayan, P. K., \& Narayan, S. (2006). Government revenue and government expenditure nexus: evidence from developing countries. Applied Economics, 38(3), 285-291.

Niskanen, W. A. (1975). Bureaucrats and politicians. The journal of law and Economics, 18(3), 617643.

Nurhaeni. (2016). Pengaruh Belanja Barang dan Jasa dan Belanja Modal Terhadap Ekuitas Dana (Survei Pada Satuan Kerja Perangkat Daerah Se-Kota Palu). E-Journal Katalogis, $4(4), 117-126$.

Patriati, R. (2010). Analisis Faktor-faktor yag Mempengaruhi Kinerja Keuangan Daerah di Provinsi Jawa Tengah. Skripsi. Universitas Sebelas Maret.

Peacock, A. T., \& Wiseman, J. (1961). Front matter, the growth of public expenditure in the United Kingdom. In The growth of public expenditure in the United Kingdom (pp. 32-0). Princeton University Press.

Puspitasari, N. L. P. L., Adiputra, I. M. P., SE, S., \& Sulindawati, N. L. G. E. (2015). Pengaruh Belanja Modal Terhadap Pertumbuhan Kinerja Keuangan Daerah Dengan Pendapatan Asli Daerah Sebagai Variabel Intervening (Studi Kasus di Kabupaten Buleleng). JIMAT (Jurnal Ilmiah Mahasiswa Akuntansi) Undiksha, 3(1).

Putra, D. M., \& Afriansyah, S. (2019). Remunerasi dan Kontribusinya terhadap Kinerja BLU
Bidang Pendidikan. Indonesian Treasury Update, 4(5), 1-9.

Rosdiana, H. (2010). Reformulating Policy on Frequency Usage Fees as Non-Tax State Revenue: Urgency and Its Implications. Journal of Indonesian Economy and Business, 25(2), 222-238.

Rosdiana, H. (2013). Does State Levies Policy Support Minapolitan Program in Indonesia. BISNIS \& BIROKRASI: Jurnal Ilmu Administrasi dan Organisasi, 20(1), 1-9.

Sani, A. K. (2018). Analisis Penyerapan Belanja Modal (Studi Pada Pemerintah Daerah Daerah Istimewa Yogyakarta). Thesis, Universitas Gajah Mada.

Sani, S. R., Syahnur, S., Masbar, R., \& Majid, M. S. A. (2018). Dynamic Causal Relationship between Government Expenditures and Revenues in Indonesia. Advances in Social Science, Education and Humanities Research, volume 292: 553-557.

Sari, K. (2017). Analisis Indikator Keuangan Penerimaan Negara Bukan Pajak (PNBP) terhadap Kinerja Keuangan Instansi Pemerintah (Studi Kasus pada Kementerian Agraria dan Tata Ruang/ Badan Pertanahan Nasional). Thesis. Program Pascasarjana Universitas Terbuka.

Saysombath, P., \& Kyophilavong, P. (2013). The causal link between spending and revenue: The Lao PDR. International Journal of Economics and Finance, 5(10), 111-116.

Sere, K. A., \& Choga, I. (2017). The causal and cointegration relationship between government revenue and government expenditure. Public and Municipal Finance, 6(3), 23-32.

Subhani, M. I., Hasan, S. A., Osman, A., \& Rafiq, T. (2012). An investigation of Granger causality between tax revenues and government expenditures. European journal of scientific research, 68(3), 340-344.

Sun, R. (2009). Municipal User Charges in the Era of Tax and Expenditure Limitations. Dissertation. University of Maryland, College Park

Sun, R. \& Jung, C. (2011). Does User-Charge Financing Reduce Expenditure Levels for the Charge-Financed Services? The American Review of Public Administration, 42(2), 170185.

Taha, R., \& Loganathan, N. (2008). Causality between tax revenue and Government spending in Malaysia. The International Journal of Business and Finance Research, 2(2), 63-73.

Taswin, T (2015). Kinerja Biro Umum dan Keuangan dalam Penerimaan Negara Bukan Pajak di Universitas Tadulako. E-Journal Katalogis, 3(7), 59-63. 
Ullah, N. (2017). The Relationship of Government Revenue and Government Expenditure: A case study of Malaysia. MPRA Paper No. 69123.

Wagner, R. E. (1976). Revenue structure, fiscal illusion, and budgetary choice. Public Choice, 25(1), 45-61.

Walelang, R. P., Alexander, S., \& Tangkuman, S. (2017). Analisis Efektivitas Penatausahaan Penerimaan Negara Bukan Pajak (PNBP) pada Kantor Pelayanan Kekayaan Negara dan Lelang (KPKNL) Manado. Jurnal EMBA: Jurnal Riset Ekonomi, Manajemen, Bisnis dan Akuntansi, 5(2). 